\title{
Germinação da semente e produção de mudas de cultivares de alface em diferentes substratos
}

\section{Germination of seeds and production of seedlings of lettuce cultivars at different substrates}

\author{
Elisângela Aparecida da Silva ${ }^{1 *}$; Vander Mendonça ${ }^{2} ;$ Mauro da Silva Tosta ${ }^{3}$; \\ Alessandra Conceição de Oliveira ${ }^{4}$ Luis Lessi dos Reis ${ }^{5}$; Diógenes Martins Bardiviesso ${ }^{5}$
}

\section{Resumo}

O presente trabalho teve como objetivo avaliar os efeitos de diferentes combinações de substratos na geminação e desenvolvimento de mudas de diferentes cultivares de alface. $\mathrm{O}$ experimento foi instalado e conduzido em viveiro telado (sombrite), em área experimental da Universidade Estadual de Mato Grosso do Sul, Unidade de Cassilândia-MS. Compararam-se as seguintes combinações de substratos: areia lavada + húmus de minhoca (2:1), esterco bovino + húmus de minhoca $(2: 1)$, Plantmax ${ }^{\circledR}+$ húmus de minhoca $(2: 1)$, areia lavada $+\operatorname{Plantmax}^{\mathbb{B}}(2: 1)$ e esterco bovino $+\operatorname{Plantmax}^{\mathbb{}}(2: 1)$, e três cultivares de alface: Crespa sem cabeça, Americana Júlia e Babá de Verão. O delineamento experimental utilizado foi o inteiramente casualizado, em esquema fatorial 5 × 3, com quatro repetições e 16 sementes por parcela. Foram consideradas para avaliação, as 10 plântulas centrais da parcela. Avaliaram-se as características: porcentagem de germinação (\%), índice de velocidade de emergência (IVE) e massa seca da plântula inteira (g). Para todas as variáveis analisadas, as cultivares Babá de Verão e Crespa sem cabeça foram as que apresentaram os melhores resultados. Esterco + húmus é o substrato ideal para se obter plântulas com maior massa seca, que implica indiretamente em maior vigor, apesar do mesmo não favorecer o IVE e a porcentagem de germinação.

Palavras-chave: Lactuca sativa L., húmus, produção de mudas

\begin{abstract}
The aim of this paper was to evaluate the effects of the combinations of substrata on germination and development of seedlings of lettuce cultivars. The experiment was carried out in a nursery, in Mato Grosso do Sul State University. There were compared the following combinations of substrata: washed sand + earthworm humus (2:1); manure bovine + earthworm humus (2:1); Plantmax ${ }^{\circledR}+$ earthworm humus (2:1); washed sand + Plantmax ${ }^{\mathbb{B}}(2: 1)$ and manure bovine $+\operatorname{Plantmax}^{\mathbb{}}(2: 1)$, and three lettuce cultivars: Crespa sem cabeça, Americana Júlia and Babá de Verão. The experimental design was entirely at random, in a $5 \times 3$ factorial outline, with four replications and 16 seeds per plot. There were considered for evaluation
\end{abstract}

1 Graduanda em Agronomia pela Universidade Estadual de Mato Grosso do Sul, Unidade de Cassilândia. E-mail: agroelis@yahoo.com.br-Bolsista PIBIC/CNPq.

2 Eng. Agrônomo, Dr. Prof. Adjunto da Universidade Federal Rural do Semi-Árido (UFERSA), Bolsista de Produtividade do CNPq, BR 110 - km 47, Bairro Pres. Costa e Silva Mossoró/RN, CEP: 59625-900. E-mail: vander@ufersa.edu.br.

3 Eng. Agrônomo, Mestrando em Fitotecnia na UFERSA, Bolsista do CNPq, e-mail: maurotosta@hormail.com.

4 Eng. Agrônomo, Mestranda em Irrigação e Drenagem. Universidade Estadual Paulista “Júlio de Mesquita Filho" (UNESP) Campus de Botucatu, Fazenda Lageado: Rua José Barbosa de Barros nº 1780, Botucatu/SP.

5 Alunos de graduação em Agronomia pela Universidade Estadual de Mato Grosso do Sul (UEMS) - Cassilândia - MS.

* Autor para correspondência 
10 central seedlings per plot. The characteristics evaluated were: germination percentage (\%), index of germination speed (IVE) and dry mass of the whole seedling (g). For all the analyzed variables, the cultivars Babá de Verão and Crespa sem cabeça presented the best results. Manure + humus was the best substratum to obtain seedling with larger development (vigor), althout it did not increase IVE and germination percentage.

Key words: Lactuca sativa L., earthworm humus, seedlings production

\section{Introdução}

A alface (Lactuca sativa L.) é a hortaliça folhosa mais consumida no Brasil, sendo fonte de vitaminas e sais minerais, com destaque no elevado teor de vitamina A (FERNANDES et al., 2002; MARQUES et al., 2003). Devido à sua alta perecibilidade e baixa resistência ao transporte, é cultivada próxima aos grandes centros consumidores, nos chamados "Cinturões Verdes". No Brasil, a maior produção de alface concentra-se no Estado de São Paulo, onde são exploradas cultivares de verão e inverno em diferentes épocas sob condições de irrigação (ANDRADE JÚNIOR; DUARTE; RIBEIRO, 1992).

A produção de mudas de hortaliças constitui-se numa das etapas mais importantes do sistema produtivo (MINAMI, 1995; SILVA JÚNIOR; MACEDO; SLUKER, 1995), pois dela depende o desempenho final das plantas nos canteiros de produção, tanto do ponto de vista nutricional, quanto do tempo necessário para a colheita e, consequentemente, do número de ciclos possíveis por ano (CARMELLO, 1995).

Na produção de mudas de hortaliças, o método de propagação mais empregado é o sistema de bandejas multicelulares de poliestireno expandido e posterior transplante para os canteiros, obtendo-se assim plantas mais vigorosas e produtivas (MARQUES et al., 2003) devido ao maior cuidado na fase de germinação e emergência, além de outras vantagens como a economia de substratos e de espaço dentro do viveiro, alto índice de pegamento após o transplante, minimização de tratamentos fitossanitários e baixos danos às raízes no momento do transplante (OLIVEIRA; SCIVITTARO; VASCONCELLOS, 1993).
Apesar das vantagens deste sistema de produção de mudas, algumas dificuldades têm sido observadas em relação às características do substrato, tais como a manutenção da umidade, o arejamento e a disponibilidade de nutrientes, fatores estes que afetam diretamente a porcentagem de germinação e o desenvolvimento das mudas, determinando a qualidade das plantas produzidas.

No contexto de produção de mudas, o substrato é um dos componentes mais sensíveis, pois qualquer variação na sua composição implica na nulidade ou irregularidade de germinação, na má formação das plantas e no aparecimento de sintomas de deficiências ou excessos de alguns nutrientes (MINAMI, 1995).

Os substratos influem diretamente na qualidade das mudas, sendo as características físicas e químicas determinantes na qualidade do mesmo, devendo estas permanecer por um longo período (FONTENO; CASSEL; LARSON, 1981). Sendo assim, o desenvolvimento da atividade de produção e comercialização especializada de mudas de hortaliças, baseia-se principalmente na pesquisa de melhores fontes e combinações de substratos. Os diversos substratos existentes constituem-se de formas comerciais de pronto uso, mas de acordo com a experiência do produtor, estes podem ser acrescidos de fertilizantes e outros materiais, como o húmus de minhoca e a casca de arroz carbonizada, que visam maximizar o seu rendimento no enchimento das células das bandejas (PUCHALSKI; KÄMPF, 2000), além de minimizar custos, pela facilidade de obtenção dos mesmos.

O presente trabalho teve por objetivo avaliar os efeitos de diferentes combinações de substratos na 
germinação e desenvolvimento de diferentes cultivares de alface, visando determinar o melhor tratamento para cada cultivar em estudo.

\section{Material e Métodos}

O experimento foi conduzido em viveiro telado, com sombrite ( $50 \%$ de luminosidade), com temperatura interna média de $27,5^{\circ} \mathrm{C}$, em área experimental da Universidade Estadual de Mato Grosso do Sul, Unidade de Cassilândia, entre os meses de setembro e outubro de 2005. O local possui latitude $19^{\circ} 05^{\prime} \mathrm{S}$, longitude $51^{\circ} 56^{\prime} \mathrm{W}$ e altitude de 471 m, de acordo com a classificação climática de Köppen, apresenta Clima Tropical Chuvoso (Aw) com verão chuvoso e inverno seco (precipitação de inverno menor que $60 \mathrm{~mm}$ ), temperatura média de $32^{\circ} \mathrm{C}$.

Utilizaram-se bandejas de poliestireno expandido (Isopor $^{\circledR}$ ) com dimensões de $18,5 \mathrm{~cm} \mathrm{x} \mathrm{19,0} \mathrm{cm} \mathrm{x}$ $11,0 \mathrm{~cm}$ de largura, comprimento e profundidade, respectivamente. Em cada bandeja, contendo 128 células com volume de $50 \mathrm{~mL}$ cada, foram colocados os cinco tipos de combinações de substratos, intercalados por fileiras de células vazias como bordadura.

O delineamento experimental foi o inteiramente casualizado, em esquema fatorial 5 (substratos) x 3 (cultivares), com quatro repetições e 16 sementes por parcela, sendo consideradas para avaliação as 10 plântulas centrais de cada parcela (Figura 1).

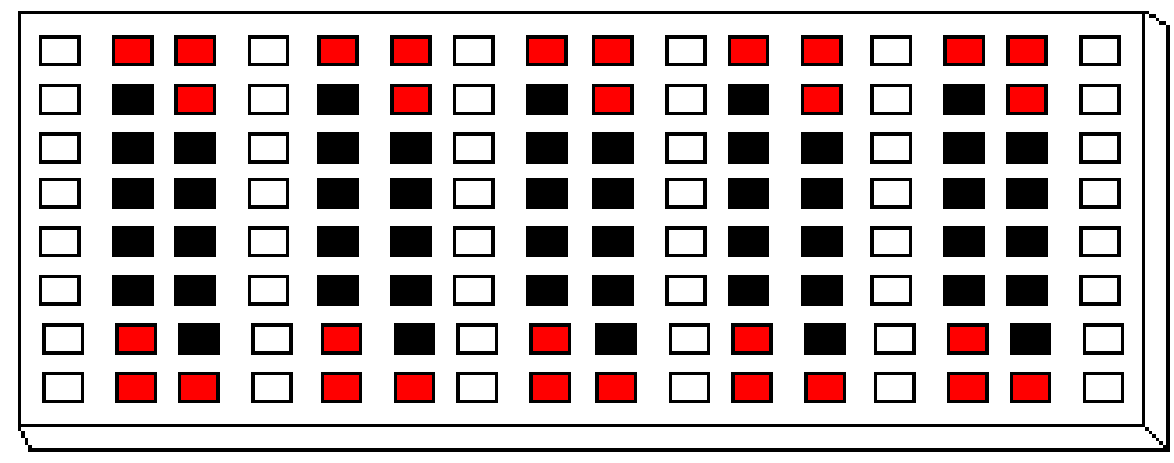

\section{$\square$ Bordadura com células vazias intercalando parcelas. \\ - Plântulas centrais consideradas na avaliação (parcela útil). $\square$ Plântulas descartadas da avaliação.}

Figura 1. Distribuição das parcelas experimentais em uma bandeja de 128 células, com destaque para as plântulas de alface consideradas para avaliação (parcela útil). Cassilândia-MS, 2005.

Os substratos utilizados foram: areia lavada + húmus de minhoca $(2: 1 \mathrm{v} / \mathrm{v})$, esterco bovino + húmus de minhoca $(2: 1 \mathrm{v} / \mathrm{v})$, Plantmax ${ }^{\circledR}+$ húmus de minhoca $(2: 1 \mathrm{v} / \mathrm{v})$, areia lavada $+\operatorname{Plantmax}^{\circledR}(2: 1 \mathrm{v} / \mathrm{v})$ e esterco bovino + Plantmax $^{\circledR}(2: 1 \mathrm{v} / \mathrm{v})$, totalizando cinco combinações alternativas, cujo resultado da análise química encontra-se nas Tabelas 1 e 2 . O substrato comercial Plantmax ${ }^{\circledR}$ Hortaliças é do tipo PxHT. 
Tabela 1. Caracterização química de diferentes substratos utilizados na produção de mudas de alface Crespa sem cabeça, Americana Júlia e Babá de Verão.

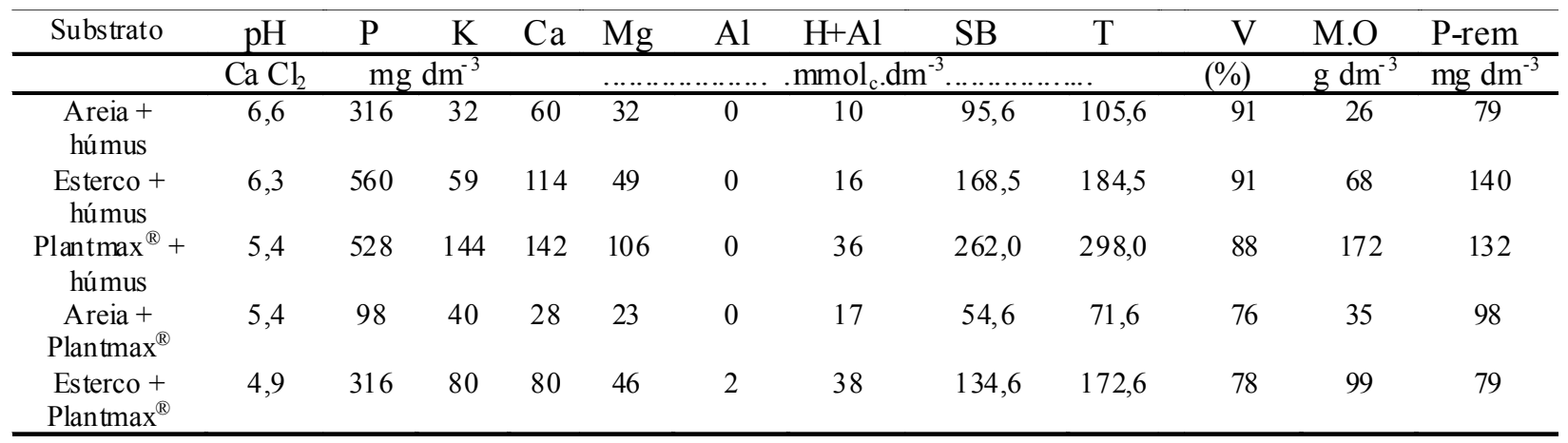

${ }^{1} \mathrm{SB}$ - soma de bases; $\mathrm{t}$ - CTC efetiva; T - CTC a pH 7,0; V - saturação de bases.

- Análise realizada pelo Laboratório de Fertilidade do Solo da UNESP- Campus Ilha Solteira.

Tabela 2. Resultados da análise dos micronutrientes nos substratos utilizados no experimento com produção de mudas de alface Crespa sem cabeça, Americana Júlia e Babá de Verão.

\begin{tabular}{|c|c|c|c|c|c|}
\hline Substrato & $\mathrm{Zn}$ & $\mathrm{Fe}$ & $\mathrm{Mn}$ & $\mathrm{Cu}$ & B \\
\hline & \multicolumn{5}{|c|}{$\mathrm{mg} \mathrm{dm}^{-3}$} \\
\hline Areia + húmus & 2,5 & 23 & 3,5 & 0,6 & 0,16 \\
\hline Esterco + húmus & 6,1 & 44 & 5,9 & 0,7 & 0,28 \\
\hline Plantmax $^{\circledR}+$ húmus & 5,0 & 38 & 8,3 & 0,6 & 2,12 \\
\hline Areia + Plantmax ${ }^{\circledR}$ & 0,9 & 35 & 1,8 & 0,3 & 0,93 \\
\hline Esterco + Plantmax ${ }^{\circledR}$ & 5,1 & 46 & 10,2 & 0,4 & 1,40 \\
\hline
\end{tabular}

- Análise realizada pelo Laboratório de Fertilidade do Solo da UNESP - Campus Ilha Solteira.

As três cultivares de alface utilizadas foram: Crespa sem cabeça (Germinação 96\% e pureza física 100\%), Americana Júlia (Germinação 93\% e pureza física 99\%) e Babá de Verão (Germinação 91\% e pureza física 99,4\%), valores estes de acordo com o fabricante. Colocaram-se duas sementes por cova (célula) de $5 \mathrm{~mm}$ de profundidade, sendo a semeadura realizada em 06/09/2005. As sementes foram adquiridas levando-se em consideração os dados de pureza e germinação, devendo os mesmos, serem os valores mais próximos possíveis, para que o efeito dos substratos não sofresse influência dessas características.

As plântulas foram avaliadas 31 dias após a semeadura, considerando a variável porcentagem de germinação. Já o índice de velocidade de emergência (IVE), baseado em Maguirre (1962), foi determinado registrando-se diariamente o número de sementes germinadas até o $12^{\circ}$ dia (18/09/2005) e considerando como emergidas, as plântulas que apresentaram os cotilédones totalmente livres e normais.

A porcentagem de germinação foi calculada de acordo com Labouriau e Valadares (1976), sendo utilizada a fórmula:

$$
\mathrm{G}=(\mathrm{N} / \mathrm{A}) \cdot 100
$$

onde: $\mathrm{G}=$ germinação; $\mathrm{N}=$ número total de sementes germinadas; $\mathrm{A}=$ número total de sementes colocadas para germinar.

Com relação à massa seca, as plântulas consideradas para avaliação em 07/10/2005, foram colocadas em estufa com circulação de ar forçado, a $60^{\circ} \mathrm{C}$ durante 72 horas, dentro de sacos de papel para posterior pesagem em balança analítica 
eletrônica $(0,001 \mathrm{~g})$. Dividiu-se a massa seca total pelo número de plântulas, obtendo o valor da massa seca por plântula.

Os dados foram submetidos à análise de variância e as médias comparadas pelo Teste de Tukey ao nível de $5 \%$ de probabilidade. As análises foram realizadas pelo programa computacional Sistema para Análise de Variância - SISVAR (FERREIRA, 2000).

\section{Resultados e Discussão}

Observando-se a Tabela 3, verificou-se que houve diferença altamente significativa entre o índice de velocidade de emergência (IVE) e a massa seca total de plântulas de alface em função dos substratos testados; e diferença significativa para a porcentagem de germinação. Em relação às cultivares, houve diferença altamente significativa apenas para o índice de velocidade de emergência. Já a interação entre substratos e cultivares, não apresentou diferença significativa.

Tabela 3. Resumo da análise de variância (Quadrado Médio) do índice de velocidade de emergência (IVE), porcentagem de germinação e massa seca total de plântulas de diferentes cultivares de alface em função de tipos de substratos. Cassilândia-MS, 2006.

\begin{tabular}{lcccc}
\hline Fontes de Variação & GL & IVE & Germinação (\%) & Massa seca total $(\mathrm{g})$ \\
\hline Substrato (S) & 4 & $95,7884^{* *}$ & $1032,5520^{*}$ & $0,0161^{* *}$ \\
Cultivar (C) & 2 & $138,4504^{* *}$ & $177,7343^{\text {ns }}$ & $0,0011^{\text {ns }}$ \\
S x C & 8 & $13,8999^{\text {ns }}$ & $251,7903^{\text {ns }}$ & $0,0008^{\text {ns }}$ \\
Bloco & 3 & 15,6813 & 148,4375 & 0,0803 \\
Resíduo & 42 & 8,7280 & 274,9275 & 0,0016 \\
\hline CV(\%) & 20,00 & 20,57 & 30,79 \\
\hline
\end{tabular}

**Significativo a $1 \%$ de probabilidade, pelo teste $\mathrm{F} ;{ }^{*}$ Significativo a $5 \%$ de probabilidade, pelo teste $\mathrm{F}$ e ${ }^{\text {ns }}$ - Não significativo.

Para o índice de velocidade de emergência (IVE), o melhor resultado foi obtido com o substrato composto por areia + Plantmax $^{\circledR}$, enquanto os piores resultados para esta variável foram observados nos substratos compostos por esterco bovino + Plantmax ${ }^{\circledR}$ e esterco bovino + húmus de minhoca (Figura 2). Segundo Hergaty (1977) apud Silva Júnior e Giorgi (1992); Epstein (1976) apud Silva Júnior e Giorgi (1992), a utilização de resíduos orgânicos na composição de substratos para o cultivo de mudas contribui sensivelmente com a aeração, capacidade de armazenamento de umidade e formação de uma adequada estrutura física ao desenvolvimento das raízes, além de fornecerem alguns micro e macro elementos essenciais à planta como resultado da intensa atividade microbiana enzimática.
No entanto, a presença de matéria orgânica (esterco bovino e húmus de minhoca) nos substratos avaliados neste trabalho, não contribuiu para aumentar a velocidade de emergência (IVE) das plântulas, quando comparados com os substratos compostos por materiais inertes, tal como a areia. Provavelmente, a estrutura física do substrato areia + Plantmax $^{\circledR}$, contribuiu significativamente para que as plântulas tivessem condições de emergirem mais rápido.

Segundo Setúbal et al. (2000), a matéria orgânica no processo de produção de mudas deve ser oferecida de forma balanceada, além dos demais componentes do substrato. Neste caso, as opções de substratos avaliadas, poderiam ser testadas em 
outras proporções ou então em outras olerícolas que necessitem da etapa de produção de mudas.

Quanto mais rápido ocorrer a germinação das sementes e a imediata emergência das plântulas, menos tempo as mesmas ficarão sob condições adversas, passando pelos estádios iniciais de desenvolvimento de forma mais acelerada (MARTINS; NAKAGAWA; BOVI, 1999). Essas condições adversas podem ser redução da umidade próximo à semente, que é essencial à germinação; ou mesmo a ação de microrganismos, que causem alguma deterioração à semente ou à plântula.

A quantidade de luz que o substrato permite chegar à semente, o pH e a densidade do mesmo, também são responsáveis por diferentes respostas germinativas (FIGLIOLA; OLIVEIRA; PIÑA-RODRIGUES, 1993). Assim, observa-se que a mistura de areia com Plantmax ${ }^{\circledR}$ favoreceu o índice de velocidade de emergência, provalvemente por reunir as características ideais à germinação e emergência.
As cultivares Babá de Verão e Crespa sem cabeça apresentaram os maiores índices de velocidade de emergência, diferindo estatisticamente da variedade Americana Júlia, onde o IVE foi inferior, conforme apresentado na Figura 2. Apesar da diferença apresentada no IVE, as sementes das cultivares utilizadas não apresentavam diferença de tamanho inicialmente.

O processo de embebição de água faz a ativação das reações químicas relacionadas ao metabolismo, retomando o desenvolvimento do embrião, sendo neste caso as proteínas, as maiores responsáveis pelo aumento do tamanho das sementes. O tegumento também exerce papel importante, pois a embebição pode ser impedida em virtude da impermeabilidade do tegumento, sendo essa uma característica inerente da cultivar (BECKERT; MIGUEL; MARCOS FILHO, 2000).

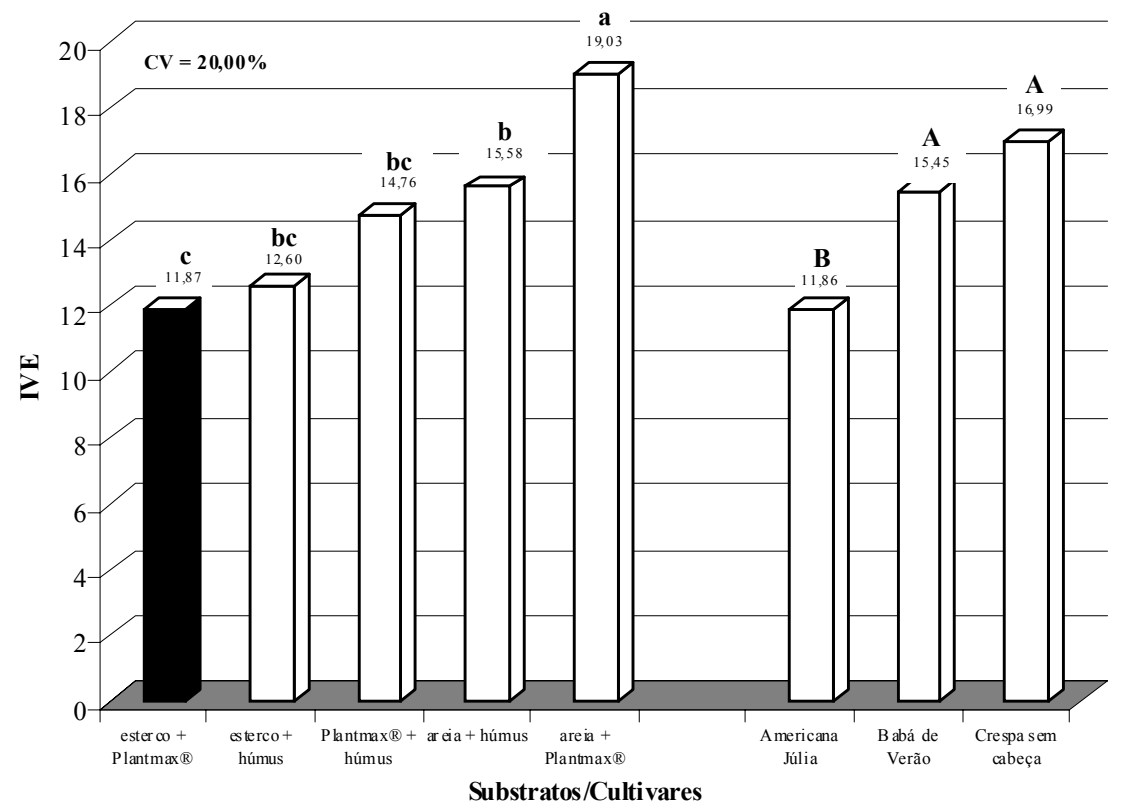

Figura 2. Médias do índice de velocidade de emergência (IVE) de plântulas de alface em função do substrato e da cultivar utilizada. Cassilândia-MS, 2006. 
Smiderle et al. (2000) trabalhando com mudas de alface, pepino e pimentão, obtiveram resultados onde o substrato Plantmax ${ }^{\circledR}$ foi o que promoveu a maior rapidez de emergência e a maior altura das plântulas.

A porcentagem de germinação mais elevada foi obtida com o substrato areia + Plantmax ${ }^{\circledR}$ conforme apresentado na Figura 3.

Substratos comerciais como o Plantmax ${ }^{\circledR}$ têm como característica uma porcentagem de microporos considerada adequada para a produção de mudas de hortaliças, o que confere a este substrato uma capacidade de retenção de água satisfatória, influenciando positivamente o desenvolvimento do sistema radicular das mudas (GUERRINI; TRIGUEIRO, 2004).

Entre as cultivares estudadas não houve diferença significativa em relação à porcentagem de germinação (Tabela 3), apesar das mesmas apresentarem uma pequena diferença inicial de porcentagem de germinação, de acordo com os dados do fabricante.

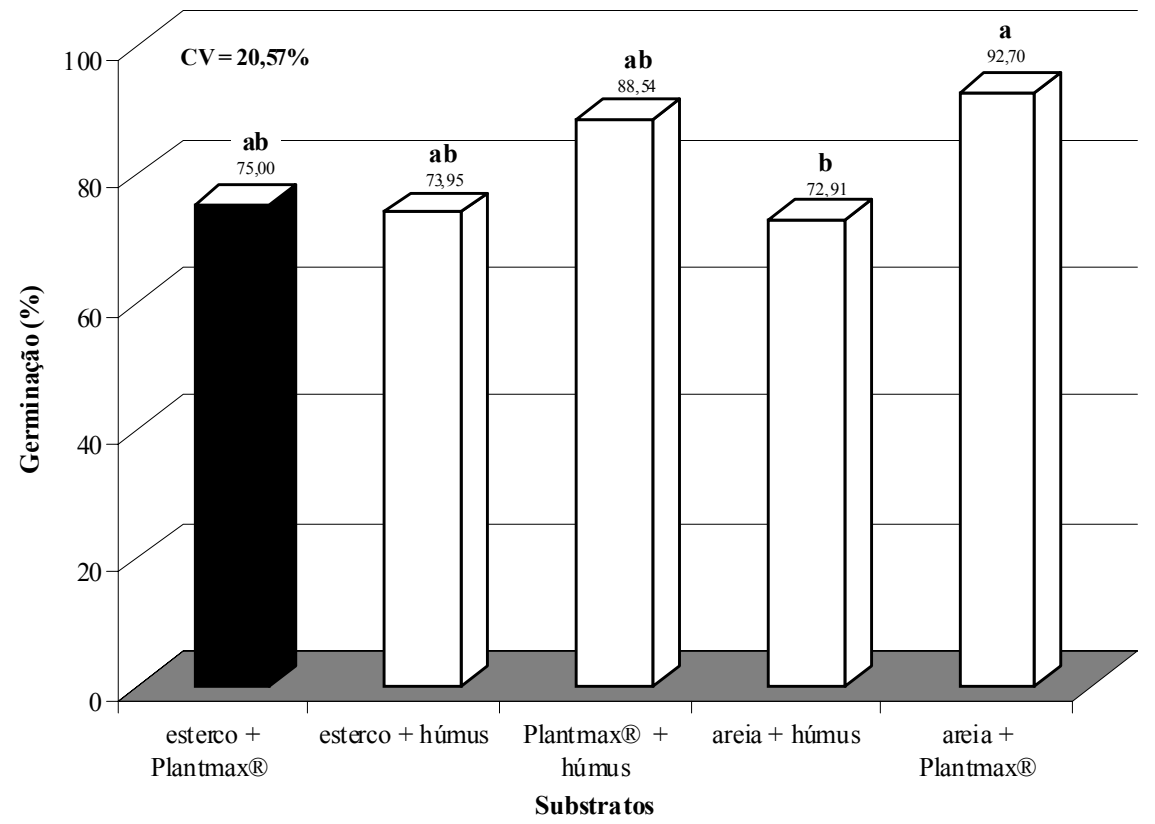

Figura 3. Médias da porcentagem de germinação (\%) de diferentes cultivares de alface em função do substrato. Cassilândia-MS, 2006.

Observando-se a Figura 4, nota-se que o substrato esterco + húmus foi o que proporcionou maior acúmulo de massa seca (g) pelas plântulas. Para as três cultivares de alface utilizadas, os valores mais baixos de massa seca foram observados no substrato areia + húmus.

Pelo resultado da análise química dos diferentes substratos apresentado nas Tabelas 1 e 2, observou-se valores expressivos em relação a todos os nutrientes, presente no substrato composto por esterco + húmus, principalmente, em relação ao $\mathrm{P}$ que é um macronutrientes de grande importância para a cultura.
A alface pode ser considerada bastante exigente em fósforo, sendo que a deficiência deste elemento reduz em muito o crescimento da planta, podendo haver mal formação da cabeça, coloração verde opaca nas folhas velhas, podendo mostrar tonalidades vermelho-bronze ou púrpura (LANA et al., 2004). O fato do substrato esterco + húmus ter tido um bom desempenho para a produção de mudas de alface de qualidade, pode estar relacionado com a reserva nutricional do mesmo, visto que os seus valores para o elemento fósforo são significantes. 


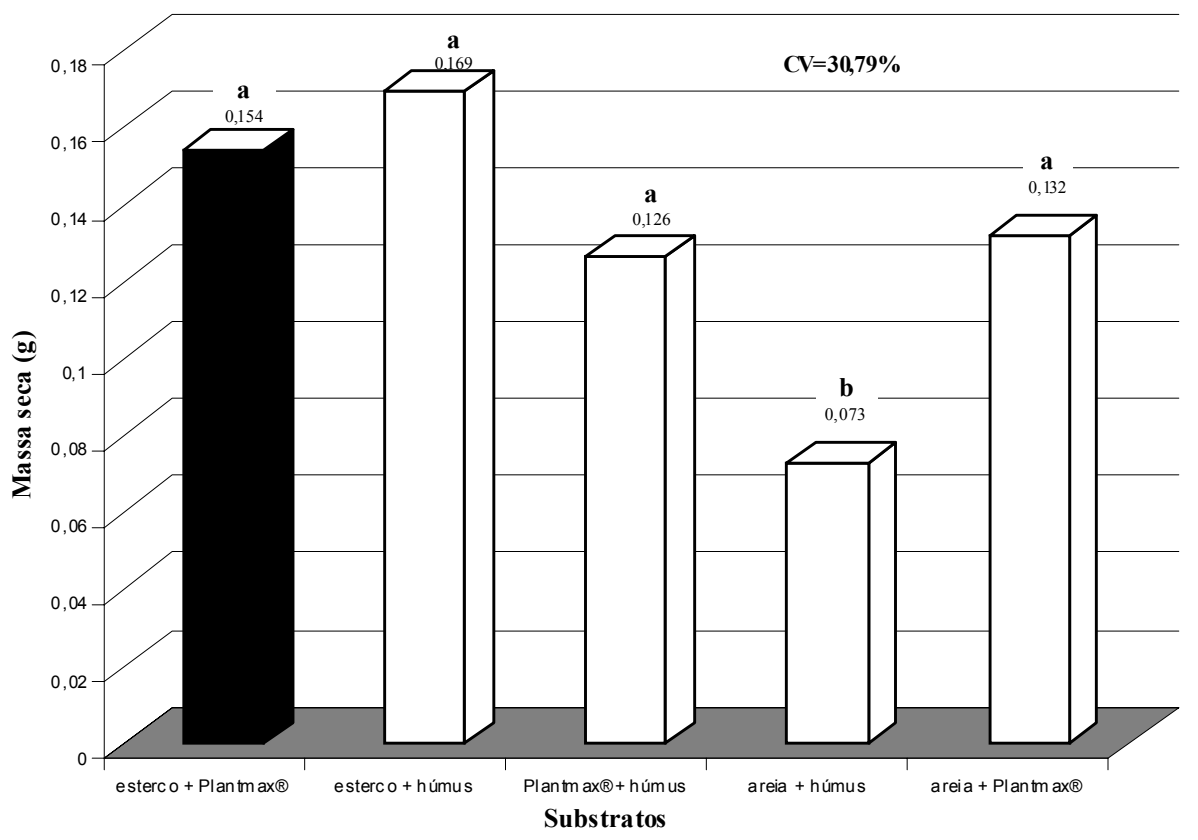

Figura 4. Médias da massa seca (g) de plântulas de alface em função do substrato utilizado. Cassilândia-MS, 2006.

O desempenho do substrato esterco + húmus se justifica pela proporção de esterco utilizada, pois de acordo com Hergaty (1977) apud Silva Júnior e Giorgi (1992); Epstein (1976) apud Silva Júnior e Giorgi (1992), a presença de esterco bovino no substrato para produção de mudas de alface com níveis acima de 75\% (1:3) é desfavorável para o processo de desenvolvimento das mudas e no experimento realizado foram utilizados $66 \%$.

O fato do substrato composto por areia não ter apresentado bom desempenho para a variável analisada (Figura 4), certamente, está relacionada à reserva nutricional deste substrato. Segundo Loach (1998) os substratos inorgânicos, como vermiculita e areia, possuem pouca ou nenhuma reserva de nutrientes.

Em relação à manutenção da umidade nos substratos, todos os tratamentos receberam a mesma quantidade de água diariamente, o que descarta o favorecimento de algum tratamento em relação à quantidade recebida, evidenciando que a capacidade de retenção de umidade é inerente a cada substrato utilizado.
Cecílio Filho et al. (1999) trabalharam com o substrato comercial Plantmax ${ }^{\circledR}$ adicionado à vermicomposto (húmus) para a produção de mudas de alface, sendo que os melhores resultados obtidos para a variável massa seca, foram com o substrato Plantmax $^{\circledR}(100 \%)$. No entanto, neste trabalho não foi observada diferença significativa para o substrato Plantmax ${ }^{\circledR}+$ húmus, o que o enquadra com um dos melhores entre os testados, diferindo apenas do substrato areia + húmus, que apresentou o menor desempenho para tal variável.

Assim, apesar do substrato areia + Plantmax ${ }^{\circledR}$ não ter apresentado os maiores resultados para a variável massa seca, ele não diferiu estatisticamente dos que apresentaram os maiores valores, e; para as características índice de velocidade de emergência e porcentagem de germinação ele foi o que apresentou melhor desempenho.

Portanto, a mistura de um substrato comercial $\left(\right.$ Plantmax $\left.^{\circledR}\right)$ com um material mais barato e disponível como a areia, torna-se uma opção para os produtores de mudas de hortaliças, pois contribui para diminuir os custos desta etapa do sistema de produção 
em bandejas. Além disso, sugere-se que mais trabalhos semelhantes a este sejam realizados, de acordo com materiais de disponibilidade regional, que favoreçam o processo, visando sempre a obtenção de mudas de qualidade, com transplante a campo em menor tempo, maximizando o uso de estufas ou viveiros e reduzindo os custos de produção.

\section{Conclusões}

Areia + Plantmax ${ }^{\circledR}(2: 1 \mathrm{v}: \mathrm{v})$ é o substrato mais adequado para a obtenção de características desejáveis, como maior velocidade de emergência e alta porcentagem de germinação.

Esterco + húmus $(2: 1 \mathrm{v}: \mathrm{v})$ proporciona maior acúmulo de massa seca em plântulas de alface, implicando indiretamente em maior vigor, apesar do mesmo não favorecer o IVE e a \% de germinação.

Para todas as variáveis analisadas, as cultivares Babá de Verão e Crespa sem cabeça foram as que apresentaram os melhores resultados.

\section{Referências}

ANDRADE JÚNIOR, A. S.; DUARTE, R. L. R.; RIBEIRO, V. Q. Resposta de cultivares de alface a diferentes níveis de irrigação. Horticultura Brasileira, Brasília, v. 10, n. 2 , p. 95-97, 1992.

BECKERT, O. P.; MIGUEL, M. H.; MARCOS FILHO, J. Absorção de água e potencial fisiológico em sementes de soja de diferentes tamanhos. Scientia Agricola, Piracicaba, v. 57, n. 4, p. 671-675, out./dez. 2000.

CARMELLO, Q. A. C. Nutrição e adubação de mudas hortícolas. In: MINAMI, K. Produção de mudas de alta qualidade. São Paulo: T.A. Queiroz, 1995. p. 27-37.

CECÍLIOFILHO, A. B.; SOUZA, A.C.; MAY, A.; BRANCO, R. B. F.; MAFEI, N. C. Avaliação da participação do vermicomposto na produção de mudas de alface. In: CONGRESSO BRASILEIRO DE OLERICULTURA, 39. 1999, Tubarão. Resumos... Tubarão: Sociedade Brasileira de Olericultura, 1999. p. 76.

FERNANDES, A. A.; MARTINEZ, H. E. P.; PEREIRA, P. R. G.; FONSECA, M. C. M. Produtividade, acúmulo de nitrato e estado nutricional de cultivares de alface, em hidroponia, em função de fontes de nutrientes. Horticultura Brasileira, Brasília, v. 20, n. 2, p. 195-200, jun. 2002.

FERREIRA, D. F. Análise estatística por meio do SISVAR (Sistema para Análise de Variância) para Windows versão 4.0. In: REUNIÃO ANUAL DA REGIÃO BRASILEIRA DA SOCIEDADE INTERNACIONAL DE BIOMETRIA, 45., 2000, São Carlos. Anais... São Carlos: UFSCar, 2000. p. 255-258.

FIGLIOLA, M. B.; OLIVEIRA, E. C.; PIÑA-RODRIGUES, F. C. M. Análise de sementes. In: AGUIAR, I. R.; PIÑARODRIGUES, F. C. M.; FIGLIOLA, M. B. (Coord.). Sementes florestais tropicais. Brasília: ABRATES, 1993. p. 137-174.

FONTENO, W. C.; CASSEL, D. K.; LARSON, R. A. Physical properties of three container media and their effect on poinsettia growth. Journal of the American Society for Horticultural Science, Alexandria, v. 106, n. 6, p. 736-741, 1981.

GUERRINI, I. A.; TRIGUEIRO, R. M. Atributos físicos e químicos de substratos compostos por biossólidos e casca de arroz carbonizada. Revista Brasileira de Ciência do Solo, Viçosa, v. 28, n. 6, p. 1069-1076, 2004.

LABORIAL, L. G.; VALADARES, M. B. On the germination of seeds of Calotropis procera. Anais da Academia Brasileira de Ciências, São Paulo, n.48, 174-186, 1976.

LANA, R. M. Q.; ZANÃO JÚNIOR, L. A.; LUIZ, J. M. Q.; SILVA, J. C. Produção da alface em função do uso de diferentes fontes de fósforo em solo de Cerrado. Horticultura Brasileira, Brasília, v. 22, n. 3, p. 525-528, jul./set. 2004.

LOACH, L. Controlling environmental conditions to improved adventitious rooting. In: DAVIS, T. D.; HAISSING, B. E.; SANKLA, N. Adventitious root formation in cuttings. Portland: Dioscorides, 1998. p. 248-273.

MAGUIRE, J. D. Speed of germination aid in selection and evaluation for seedling emergence and vigor. Crop Science, Madison, v. 2, n. 2, p. 176-177, 1962.

MARQUES, P. A. A.; BALDOTTO, P. V.; SANTOS, A. C. P.; OLIVEIRA, L. Qualidade de mudas de alface formadas em bandejas de isopor com diferentes números de células. Horticultura Brasileira, Brasília, v. 21, n. 4, p. 649-651, out./dez. 2003.

MARTINS, C. C.; NAKAGAWA, J.; BOVI, M. L. Efeito da posição da semente no substrato e no crescimento inicial das plântulas de palmito vermelho (Euterpe espiritosantensis Fernades - Palmae). Revista Brasileira de Sementes, Brasília, v. 21, n. 1, p. 164-173, 1999.

MINAMI, K. Produção de mudas de alta qualidade em horticultura. São Paulo: T.A. Queiroz, 1995. 
OLIVEIRA, R. P.; SCIVITTARO, W. B.; VASCONCELLOS, L. A. B. C. Avaliação de mudas de maracujazeiro em função do substrato e do tipo de bandeja. Scientia Agricola, Piracicaba, v. 50, n. 2, p. 261-266, 1993.

PUCHALSKI, L. E. A.; KÄMPF, A. N. Efeito da altura do recipiente sobre a produção de mudas de Hibiscus rosasinensis L. em plugs. In: KÄMPF, A. N.; FERMINO, M. H. (Ed.). Substratos para plantas: a base da produção vegetal em recipientes. Porto Alegre: Genesis, 2000. p. 209-215.

SETUBAL, J. W.; NETO, A. F. C. Efeitos de substratos alternativos e tipos de bandejas na produção de mudas de pimentão. Horticultura Brasileira (Suplemento), v. 18, p. 593-594, jul. 2000.
SILVA JUNIOR, A. A.; GIORGI, E. Substratos alternativos para a produção de mudas de tomate. Florianópolis: EPAGRI, 1992. (Boletim Técnico, 59).

SILVA JÚNIOR, A. A.; MACEDO, S. G.; SLUKER, H. Utilização de esterco de peru na produção de mudas de tomateiro. Florianópolis: EPAGRI, 1995. (Boletim Técnico, 73).

SMIDERLE, O. J.; SALIBE, A. B.; HAYASHI, A. H.; PACHECO, A. C.; MINAMI, K. Produção de mudas de alface, pepino e pimentão desenvolvidas em quatro substratos. In: $40^{\circ}$ Congresso Brasileiro de Olericultura, 2000. Horticultura Brasileira (Suplemento), Brasília, v. 18 , p. 510-512. 